\title{
O REVÉS JUDAICO NOS CONTOS DE RAWET E CLARICE
}

\author{
Thays Freitas de Almeida Pena* \\ Stefania Rota Chiarelli*
}

\begin{abstract}
RESUMO: Há diferentes formas de ser judeu. Nesse sentido, esta pesquisa visa refletir acerca das marcas da tradição judaica na trajetória dos autores Samuel Rawet e Clarice Lispector, além de discorrer sobre a maneira particular que os autores vivenciaram o judaísmo. Como aporte teórico, utilizamos os apontamentos de Amós Oz e Fania Oz-Salzberger, Jacó Guinsburg, Michael Brenner, além de outros estudos referentes ao tema em questão. A experiência judaica é vivenciada singularmente: seja pelos costumes, seja pela tradição judaica, por compartilhar uma mesma linhagem ou pelos valores judaicos. Portanto, compreendemos que em Rawet e Clarice o judaísmo é experienciado em suas obras de forma própria.
\end{abstract}

PALAVRAS-CHAVE: Judaísmo; Tradição judaica; Samuel Rawet; Clarice Lispector.

\section{O judaísmo: uma questão}

Quem é o judeu? O que o faz ser pertencente ao judaísmo? Quem está apto a classificar um indivíduo como judeu? Longe de esgotar tais questões, Amós Oz elucida ao dizer que: "nós, judeus, somos notoriamente incapazes de concordar sobre qualquer coisa que comece com as palavras 'nós judeus"' (2015, p. 160). Na obra Os judeus e as palavras (2015), o autor e sua filha Fania Oz-Salzberger delimitam ensaísticamente a relação dos judeus e sua continuidade com o texto, abordando temas caros ao judaísmo e seus fatos históricos. Dessa maneira, os autores entendem que classificar um indivíduo como judeu ultrapassa o preenchimento de requisitos padronizados e que o próprio ato de legitimar o judaísmo em outra pessoa é no mínimo infrutífero.

Há diferentes formas de ser judeu, isto é, há diferentes formas de viver o judaísmo. "Judeus é um substantivo plural com numerosas singularidades" (OZ; OZ-SALZBERGER, 2015, p. 188), logo, seja pelos costumes, seja pela tradição judaica, por compartilhar uma mesma linhagem, ou pelos valores judaicos, fato é que a experiência judaica é vivenciada singularmente por cada indivíduo. Dito isso, é importante compreender que a continuidade judaica está ligada diretamente ao texto, de modo que Amós Oz e Fania Oz-Salzberger afirmam: "a nossa não é uma linhagem de sangue, mas uma linhagem de texto" (2015, p. 15). Eles inferem que será através das palavras que os judeus encontrarão sua forma de sobrevivência e perenidade.

Os autores lembram que a nacionalidade judaica histórica, étnica, genética é um relato

\footnotetext{
${ }^{*}$ Doutoranda em Literatura Comparada na Universidade Federal Fluminense (UFF). Mestre em LETRAS pela Universidade Federal do Amazonas (Ufam). Professora da Faculdade de Tecnologia Senac Rio.

** Doutora em Letras pela Pontifícia Universidade Católica do Rio de Janeiro (Puc-Rio). Professora Adjunta da Universidade Federal Fluminense (UFF).
} 
de fratura e de calamidade, e que como tal, suas diferentes escalas de medidas são as palavras. Essa relação com o texto inicia desde muito cedo na cultura judaica, pois os judeus começavam a "aculturar suas crianças à narrativa antiga tão logo os pequenos começassem a compreender as palavras, aos dois anos, e lê-las, já na precoce idade de três anos. A escolaridade, em suma, começava logo depois de desmamar" (OZ; OZ-SALZBERGER, 2015, p. 22).

Sendo assim, a cultura de letramento é atrelada desde a infância ao que há de mais íntimo em ser judeu, dado que diante da barbárie das perseguições, a sobrevivência dessa continuidade estava na palavra.

Amós Oz e Fania Oz-Salzberger defendem a ideia de que "para poder se conservar como família, uma família judia obrigatoriamente dependia de palavras. Não quaisquer palavras, mas palavras que vinham dos livros" (2015, p. 40). Posto que pais judeus não meramente recitavam os fundamentos da fé, mas os liam, pois mesmo com poucos recursos e sem possibilidade de adquirir outras obras, os textos rituais que narravam estavam em livros. Os autores evidenciam que:

\footnotetext{
Mesmo que não pudessem achar nenhuma sinagoga num raio de muitos quilômetros, nem rabinos, alguém em casa era capaz de recitar migalhas de Torá, versículos cruciais, formulações básicas e o esqueleto da História. Talvez apenas um cântico. Ainda assim podiam passar adiante para seus descendentes um legado escrito, ainda que em forma oral. Mesmo desprovidos de livros ou pouco instruídos, os judeus sempre tinham o texto. (OZ; OZ-SALZBERGER, 2015, p. 41)
}

É necessário também mencionar o iídiche, que tanto fora utilizado nesse continuum judaico durante a diáspora. "O iídiche (ou ídiche, formas traduzidas de yidich para o português) originou-se, ao que tudo indica, nas áreas fronteiriças franco-germânicas, às margens do Reno, por volta do século X” (GUINSBURG, 1996, p. 25). O aparecimento e desenvolvimento do í́diche é vinculado às camadas mais humildes e menos letradas dos judeus ashkenaze (oriundos da Europa Oriental). Jacó Guinsburg afirma que "todo o processo de vida espiritual e material foi perpassado e entretecido no ídiche. Ele permeava o sistema todo pelo qual o menino no beider era alfabetizado e introduzido na Torá” (1996, p. 33). Assim, o idioma foi transformando-se ao longo do tempo de acordo com seus falantes e o contexto no qual estava inserido, sendo a língua materna da maioria dos judeus ashkenaze.

Para além desses aspectos, a relação do judaísmo com a palavra reverbera na literatura em aspectos como a diáspora, a errância, o nomadismo e a imigração, que fazem parte de inúmeras obras. Regina Igel (1997) traça um quadro do componente judaico na literatura brasileira adotando um critério para considerar as obras como literatura judaica: autores que se considerem judeus e possuam temática judaica. Ela afirma: 
Considera-se judeu ou judia para os fins deste exame, quem assim se apresentar na sua escrita, ou por ter nascido de pais judeus (pai, mãe ou ambos), por assim designar-se de acordo com o seu conhecimento de fé e de culturas judaicas, ou por ter se convertido ao judaísmo. (IGEL, 1997, p. 4)

Entretanto, a autora esclarece que esse critério não esgota as possibilidades da questão, pois responder à pergunta sobre quais autores seriam judeus ou não retorna a intrincada pergunta: quem é o judeu? Igel classifica Samuel Rawet como pertencente a uma literatura de temática judaica, no entanto, a partir de seus critérios, a autora exclui Clarice Lispector desse rol pela não afirmação da autora sobre suas origens judaicas. Porém, entendemos que a posição de Clarice Lispector quanto a sua religiosidade e nacionalidade não se contradizem, ou apagam sua origem estrangeira e sua prosa inevitavelmente marcada pela experiência judaica. Ressaltamos que a perspectiva da pesquisa em questão está em conformidade com o pensamento de Amós Oz e Fania Oz-Salzberger sobre a experienciação individualizada do judaísmo, considerando a questão judaica como atravessada por múltiplas chaves de leitura.

A forma de se relacionar com a palavra é um ponto significante para Rawet e Clarice. Em Rawet, retomando a formulação de Rosana Kohl Bines, há uma árdua procura pela “palavra exata", aquela que atingiria a "simplicidade e naturalidade dos fatos" (RAWET, 2008, p. 119). Bines afirma que para dizer a vida Rawet "faz uma aposta arriscada na linguagem, impregnando-a de uma fúria que lhe permita penetrar o núcleo duro das coisas” (2008a, p. 13). Na prosa rawetiana, o cerne é a busca exasperada dessa exatidão da palavra e da captura do momento. Em Clarice, ocorreria a busca de "encostar a palavra à coisa e atingir além do signo (...) Dá-se a articulação do corpo e da língua, essa escrita do grão da voz raramente chega a dizer" (CASTELLO BRANCO; BRANDÃO, 2004, p. 122). Ambos se deparam com a impossibilidade do dizer, de atingir o além do signo, tentando sorver o que há de mais íntimo através da literatura.

Para Rawet e Clarice, a escrita torna-se pátria. Não há dúvidas quanto a nacionalidade brasileira dos autores, que escolhem a língua portuguesa como morada, local de pertencimento e forma de estar no mundo. Theodor Adorno afirma que "no seu texto o escritor se põe como em casa. [...] Para quem não tem mais pátria, para esse sim a escrita é um deleite" (ADORNO, 2008, p. 83). O autor se vale da imagem de que o escritor se instala no texto como em sua casa, sustentando a ideia de que escrever se torne a morada para quem não tem mais pátria.

Sobre esse modo de pertencimento na escrita, consideramos que, em Rawet, a linguagem se afigura como pátria, espaço que "abriga e equaciona os dilemas e conflitos referentes aos múltiplos pertencimentos" (CHIARELLI, 2007, p. 46). Processo de certa forma similar 
se dá em Clarice. Diante da impossibilidade de pertencer a uma só linguagem, os autores procuram tornar a ficção um território factível, que abarca suas vivências. Através dos contos, a prosa rawetiana e clariceana se instaura como local de pertencimento, onde reinventam costumes e relações sociais através do trabalho com a linguagem. O fim do século XIX e início do século XX foi um período marcante na história da imigração judaica. A vinda de imigrantes de diversas proveniências tinha um objetivo em comum: substituir a mão de obra dos escravos recém-libertos. Segundo Berta Waldman, "os imigrantes funcionavam como braço de trabalho barato submetido à força do poder hegemônico que os acolhia, mas também os condicionava a um lugar delimitado" (2003, p. XVI).

Como vimos anteriormente, devido aos pogroms, durante esses anos, o fluxo imigratório judaico foi expressivo e o Brasil foi um dos países que mais recebeu judeus nesse período. Michael Brenner (2013, p. 354) apresenta que, de acordo com o American Jewish Yearbook, em 1930 os EUA era o país com a maior comunidade judaica do mundo com 4,2 milhões de judeus em seu território. O Brasil começa a figurar nessas estatísticas em 1948, apresentando 110 mil comunidades judaicas e sendo um dos países com o maior número de judeus daquele período. O contexto político brasileiro nesse período foi decisivo para as comunidades judaicas. No início do século XX, as autoridades federais brasileiras controlavam o fluxo imigratório no país, determinando como critério "manter no campo e na cidade homens disciplinados, trabalhadores incorporados de forma orgânica ao sistema de produção" (WALDMAN, 2003, p. XVI). Logo, o trabalho tornou-se critério de avaliação social e racial. Entre os anos de 1930 e 1945, quando o Brasil estava sob o regime de Getúlio Vargas, essa medida foi retomada.

O objetivo era usar um "saber técnico para detectar os focos de disfunção social e racial, tentando dominar os movimentos aleatórios, punir revoltas e alijar os "males" que atormentam o corpo social" (WALDMAN, 2013, p. XVI). Dessa maneira, o racismo e o nacionalismo caracterizaram o Estado Novo, cujo discurso vinha ganhando forças desde o final do século XIX. Sob esses critérios, os judeus se tornaram um dos grupos imigrantes de maior interesse político nacional. Todavia, a interferência de Getúlio Vargas na imigração judaica da época é objeto de discussões. Restrições severas foram impostas aos imigrantes italianos, japoneses e alemães: entidades de imigrantes foram obrigadas a "nacionalizar" seus nomes e o ensino e a publicação de jornais em língua estrangeira foram proibidos. As medidas adotadas denotam a xenofobia do governo naquele período, resultando em desdobramentos traumáticos para aquela população.

A década de 1940 foi um período de transformação no campo literário. A Semana de 
Arte Moderna, que deu início a uma revolução nas artes brasileiras em 1922 já se esvaíra. Conforme Antonio Candido, depois de 1940 começa a constituir-se um período novo, "o Modernismo regionalista, folclórico, libertino, populista, se amaina, inclusive nas obras que os seus próceres escrevem agora - revelando preocupação mais exigente com a forma ou esforço antissectário no conteúdo" (2011, p. 133-134). A escrita assume novos feitios, e certa prosa intimista surge com força nesse cenário. Diante dessa nova maneira de fazer literatura, Alfredo Bosi afirma:

Em suma, a melhor posição em face da história cultural é, sempre, a da análise dialética. Não é necessário forçar o sentido das dependências: bastaria um sumário levantamento estilístico para apontá-las profusamente; nem encarecer a extensão e a profundidade das diferenças: estão aí as obras que de 30 a 40 e a 50 mostram à sociedade que novas angústias e novos projetos enformavam o artista brasileiro e o obrigavam a definir-se na trama do mundo contemporâneo. (2006, p. 411)

À vista disso, a literatura produzida na década de 1940 estabeleceu-se como espaço de transição para uma renovação que se firmaria na década seguinte. Para Bosi, "é preciso descobrir, se não reinventar, o caminho que vai do eu narrativo aos objetos" (2015, p. 15), afirmando que esse é o cerne da invenção temática de Clarice. Pois, seja ao falar de desencontros nas relações familiares, animais opacos ou de crianças, a prosa clariceana produz efeitos de estranheza radical: "o fato banal e infinitamente misterioso de que existem, fora e além do eu, as coisas e outras consciências" (BOSI, 2015, p. 15). Ainda para o autor, Clarice Lispector partilha esse caráter especulativo da linguagem com alguns textos de Samuel Rawet e de Nelida Piñon, “cujas frases, porém, se emaranham nas teias de uma retórica do Imaginário; a manipulação do frenesi impede a palavra de comungar com a pureza viva dos seres” (BOSI, 2015, p. 22).

Devido ao momento político vivido no Brasil naquele período, o fator do nascimento significava muito em um país nacionalista. Desse modo, ser uma escritora estrangeira e judia poderia atribuir rótulos repelidos veementemente por Clarice. De acordo com Nelson Vieira, a autora não desejava prejudicar a sua identidade brasileira e sobretudo a sua identidade de escritora brasileira, "porque a alternativa seria a sua colocação numa espécie de 'gueto literário', num estereótipo de escritora étnica que na altura de sua época, limitaria a sua voz brasileira e modernista" (VIEIRA, 2008, p. 499). Vieira ainda afirma que esses rótulos prejudicariam o alcance literário da autora ao ser taxada de "escritora judia", isolando-a dentro da literatura brasileira. A vaga ideia de categorizar e definir Clarice a partir do local de seu nascimento, ou qualquer outro fator, é oposta a tudo que a autora evoca em sua literatura, que desperta o estranho, o heterogêneo, o diferente, o que não é coeso.

É conhecida a reação incisiva da autora quanto referidos os tópicos do sotaque ou 
nacionalidade: "Eu sou judia você sabe. Mas não acredito nessa besteira de judeu ser o povo eleito de Deus. [...] Eu, enfim, sou brasileira, pronto e ponto" (LISPECTOR apud COUTINHO, 1980, p. 168). Não há dúvidas sobre a nacionalidade brasileira de Clarice, no entanto o que se ressalta nesta análise são as afinidades e paralelos com a tradição judaica suscitadas por sua obra. Não é nosso interesse limitar Clarice dentro de uma ótica judaica, mas compreender sua obra através da experiência de ser uma escritora brasileira também judia, ecoando a visão de Nelson Vieira quando declara que "sua experiência cultural heterodoxa e pluralista de judia brasileira contribuiu para as expressões de criatividade e multiplicidade evidentes na sua arte brasileira escrita em português" (VIEIRA, 2008, p. 502).

Berta Waldman observa a dualidade no jogo de palavras utilizado por Clarice nessa mesma entrevista citada na qual a autora afirma ser judia, mas logo após nega o fato. Nessa operação, Clarice lida com o judaísmo tentando se desvencilhar dele. Berta Waldman afirma que curiosamente seus textos têm a marca dessa mesma operação, deixando-se mover por deslocamentos: "dubitativa e errática, sua linguagem busca aproximar-se da nebulosidade do que não tem nome, do que não pode ser representado, o que a obrigada a retornar" (WALDMAN, 2003, p. 29). O que ocorre então é dupla vinculação cultural de Clarice, pois "a pessoa dependente de uma determinada cultura não precisa conhecer explicitamente a sua estrutura para sofrer seus efeitos" (WALDMAN, 2003, p. 29). É importante lembrar que a família de Clarice era judia e praticante dos ritos judaicos.

Segundo Gotlib (1995, p. 94), é provável que já estudasse no Colégio Hebreu-ÍdicheBrasileiro, onde tem passagens de registro datando o ano de 1931. Além disso, Clarice tinha o hebraico entre as disciplinas obrigatórias e o iídiche como disciplina optativa no Colégio, mostrando que vivenciou a cultura judaica também na escola. É inegável a possibilidade de a cultura judaica ter ocupado uma parte da sua mente, para além de ter sido elemento estruturante da construção linguística da autora.

Foi na escrita que Clarice encontrou o local de refúgio e de liberdade, pois naquele território esse eu dividido e contraditório poderia "pertencer" e se libertar de qualquer amarra, à medida que a escrita se torna um símbolo de si mesma. Diante dos paralelos entre a escrita da autora e o judaísmo, a busca pela palavra se revela como aparente afinidade, pois

Sabe-se que a palavra ocupa um lugar central na tradição judaica. É a interdição da representação de Deus fora da escrita que atribui a esse registro simbólico a importância que ele tem. Se Deus persiste na palavra é ali que ele tem que ser procurando. Assim, a religião, a cultura, o pensamento judaico desenvolveram-se a partir da inviabilidade de se achegar ao Pai por outro caminho que não fosse $o$ da leitura e o da interpretação da lei que um dia Deus concedeu a Moisés e aos profetas". (WALDMAN, 2003, p. 24) 
Como vimos, há uma forte e significativa relação entre o judaísmo e a escrita. Jacques Derrida denomina o discurso judaico como "imperativo intepretativo" quando disserta sobre Le livre des questions do filósofo Edmond Jabés:

\begin{abstract}
Pois o que Jabés nos ensina é que as raízes falam, que as palavras querem crescer e que o discurso poético está cravado numa ferida: trata-se de um certo judaísmo como nascimento e paixão da escritura. Paixão da escritura, amor e sofrimento da letra, acerca da qual não se poderia dizer se o sujeito é o judeu ou a própria Letra. Talvez raiz comum de um povo e da escritura. Em todo o caso, destino incomensurável, que insere a história de uma "raça saída do livro". (DERRIDA, 1995, p. 54)
\end{abstract}

Esse vínculo com a escrita é algo muito caro a Clarice, que a descreve com a seguinte metáfora: "então escrever é o modo de quem a palavra como isca: a palavra pescando o que não é palavra. Quando essa não palavra - a entrelinha — morde a isca, alguma coisa se escreveu" (LISPECTOR, 1999, p. 385). Em A hora da estrela, o narrador afirma que "enquanto eu tiver perguntas e não houver respostas continuarei a escrever" (LISPECTOR, 2017, p. 47), emergindo um aspecto que dialoga com a tradição cultural judaica, em que a literatura pós-bíblica do "Midrash" (comentários bíblicos) "representa uma busca perpétua onde há mais perguntas do que respostas" (VIEIRA, 1987, p. 92). A relação do judaísmo com o texto promove variadas leituras, dada a importância da palavra para a tradição judaica: propiciar múltiplas possibilidades de sentido a cada leitura dos textos sagrados.

Derrida explana a respeito da tradição judaica e da interpretação, afirmando que a Lei se torna Questão e o direito à palavra se confunde com o dever de interrogar. O livro do homem é um livro de questão. "A toda pergunta, o judeu responde com uma pergunta" (DERRIDA, 1995, p. 57). O narrador de $A$ hora da estrela afirma: "Este livro é um silêncio. Este livro é uma pergunta" (LISPECTOR, 2017, p. 51), apresentando clara afinidade com o referido pressuposto da tradição judaica. Segundo Nelson Vieira, “a linguagem de Clarice Lispector é um testamento a esta espiritualidade humana" (1987, p. 93).

A atração de Clarice pelo questionamento percorreu toda sua obra, cujos personagens estão mergulhados em profunda inquietude e constante estranhamento. Essa marca é também um aspecto importante do judaísmo, cujo Talmude (livro sagrado judaico que contempla as discussões rabínicas) se caracteriza por mais perguntas do que respostas, o que permite espaço aberto para o questionamento. Segundo Bella Jozef, "o Talmude nos ensina sobre os diferentes níveis de leitura de um texto e indica-nos como quinto nível o que talvez seja o mais importante - a voz do mistério — que faz com que a luz da esperança não se apague" (JOZEF, 2009, p. 248). Em vista disso, Clarice coaduna-se à tradição judaica através do modo de fazer literatura e da maneira que está ligada a todas as perguntas evocadas pela palavra.

Outro aspecto importante de intersecção entre a escrita clariceana e a cultura judaica é 
o humor através da ironia. Em Laços de familia esse traço já se antecipa pelo título da obra, que possui narrativas nas quais os laços familiares aprisionam, ao invés de acolher. Exemplo disso é o conto "Feliz aniversário", no qual a matriarca D. Anita nutre profunda ojeriza pelos familiares. A protagonista contradiz o paradigma da avó afetuosa e meiga, principalmente no momento em que parte o bolo de forma feroz e cospe no chão, em sinal de desprezo por todos ali presentes: "Olhou-os com sua cólera de velha. Pareciam ratos se acotovelando, a sua família. Incoercível, virou a cabeça e com força insuspeita cuspiu no chão" (LISPECTOR, 1960, p. 71). Logo, a ironia é um recurso estilístico marcante na escrita da autora.

No conto "Amor", Clarice lança mão da ironia ao mencionar por vezes a quão "verdadeira" e "boa" era a vida que Ana levava. Quando, na verdade, tudo não passava de uma ilusão e de uma representação: "Quanto a ela mesma, fazia obscuramente parte das raízes negras e suaves do mundo. E alimentava anonimamente a vida. Estava bom assim. Assim ela o quisera e escolhera" (LISPECTOR, 1960, p. 25). Os adjetivos utilizados para descrever a vida que Ana levava estão carregados de ironia: "os filhos de Ana eram bons"; "os dias realizados e belos"; "uma aparência harmoniosa"; "o homem com quem casara era um homem verdadeiro" e "os filhos que tivera eram filhos verdadeiros". É quando Ana tem seu grande momento ao ver um cego mascando chiclete, quando se dá um grande revés: "tudo era estranho, suave demais, grande demais" (LISPECTOR, 1960, p. 28). Após tal experiência, Ana não seria mais a mesma, pois "hoje de tarde alguma coisa tranquila se rebentara, e na casa toda havia um tom humorístico, triste” (LISPECTOR, 1960, p. 33). Ana não saberia como ser a mesma, uma vez que a visão do cego desconstruiu sua suposta tranquilidade.

A bora da estrela constitui outra obra que expressa vivamente os elementos judaicos na obra clariceana. "Simples, mas complexa, a narrativa questiona a representação artística, a justiça social e o significado da vida. Lispector aborda essas questões através da ironia e da paródia, inventando uma voz narrativa que expressa tanto desafio quanto empatia" (VIEIRA, 1995, p. 140). A narrativa acontece em torno de uma moça nordestina que "era incompetente pra vida": o narrador ainda completa ao dizer que "há os que têm. E há os que não têm. É muito simples: a moça não tinha. Não tinha o que? É apenas isso mesmo: não tinha" (LISPECTOR, 2017, p. 58-59). Em carta de 1946 para Fernando Sabino, a escritora já atencipava o processo de construção da protagonista da obra $A$ hora da estrela, que seria lançada somente trinta e um anos depois em 1977. Clarice revela que "tratava-se de uma moça que, porque era curta de espírito e muito lenta, forçava muito esse espírito fraco e isso dava uma espécie de santidade. [...] Mas, porque ela era um desses fracos, ela forçava o espírito para ver a realidade" (LISPECTOR, 2011, p. 50). A ligação com a tradição judaica 
acontece já na escolha do nome da protagonista: Macabéa, traçando uma alusão à história bíblica dos macabeus:

\begin{abstract}
As aventuras dos Macabeus, um grupo de zelotas cujas façanhas e lutas pareciam ser sem esperanças contra o poder dominante dos gregos, são narrados nos livros secretos da Bíblia, especificamente nos Livros dos Macabeus. A história dos macabeus tem lugar entre a reconstrução do Templo e a época antes de Cristo (174134AC). Durante a campanha para helenizar os judeus, o Rei dos gregos, Antiocus Epifanes, dessacralizou o Templo no Monte Sion, proibiu a leitura da Torá e a prática de ritos religiosos a fim de impor a sua crença pagã. Com Jerusalém sob o domínio deste rei, aqueles que eram fiéis a um só Deus foram perseguidos. Segundo Elias Bickerman no seu livro O Deus dos Macabeus: "Era a fidelidade dos mártires teimosos, a coragem dos Macabeus que salvaram para os judeus e para a Humanidade, o princípio do monoteísmo”. (VIEIRA, 1989, p. 208)
\end{abstract}

Macabéa representa a represssão social: parcialmente alfabetizada, economicamente pobre e socialmente oprimida, a nordestina emigra para o Rio de Janeiro. Sobre o surgimento da personagem, Clarice afirma: "é que numa rua do Rio de Janeiro peguei no ar de relance o sentimento de perdição no rosto de uma moça nordestina” (LISPECTOR, 2017, p. 48). A protagonista não tem consciência da opressão que sofre, apenas continua existindo, pois não sabe outra maneira de ser. Assim como os macabeus da história bíblica, ela também resiste através da sua teimosia de ser no mundo.

Embora tenha sua existência direcionada ao fracasso, Macabéa persiste em sobreviver. O narrador compara a protagonista ao capim, pois "ela era subterrênea e nunca tinha tido floração" (LISPECTOR, 2017, p. 52). Assim como essa espécie de vegetação, que tem por peculiaridade a resistência, a protagonista sobrevive à opressão dos poderosos, representando uma camada da sociedade brasileira renegada e oprimida. Ademais, Clarice demonstra novamente a afinidade com a ideologia judaica quando nos apresenta a ligação de Macabéa com as palavras, resgatando a ideia da importância da escrita para a tradição.

Quase analfabeta, Macabéa exercia com dificuldade a atividade de datilógrafa. Uma relação interessante com as palavras, uma vez que "ela era calada (por não ter o que dizer) mas gostava de ruídos. Eram vida.” (LISPECTOR, 2017, p. 65). Macabéa que convivia melhor com o silêncio, tinha por árduo ofício datilografar e escutava a Rádio Relógio todas as madrugadas, a fim de pescar entre uma palavra e outra, algum ruído que pudesse converter em perguntas infindáveis. Todavia, não consegue se apropriar dos sentidos das palavras que escuta. Dessa forma, permanece numa constante peleja cultural que não terá sucesso, pois aquelas informações não tinham conexão com a realidade na qual estava inserida.

Ainda nesse viés, a protagonista, que tinha a palavra como sustento e os ruídos sendo a sua existência, vivia no espaço do entre: sempre deslocada e fora de lugar. A emigrante nordestina não se integra à cultura urbana carioca, bem como vive cindida entre duas 
histórias. De acordo com Bella Jozef, "ela sente como uma dor a não familiaridade do lugar. Sua morte interrompe o desenvolvimento da própria indiferença” (2009, p. 246). Macabéa sente-se alheia ao mundo, que parece ter sido feito para fazê-la falhar: "acho que não sou muito gente. [...] É que não me habituei” (LISPECTOR, 2017, p. 78). Nesse aspecto reside a grande questão de Macabéa: fazer-se humana, ser possível ou ser gente.

Essa também a questão de Clarice: como é possível ser? Como existir? Ávida de pertencer, mas sem saber ao certo como fazê-lo, a autora obtém essa chave através de seus personagens. Clarice viveu nas margens, nas fendas, entre fronteiras culturais, fertilizando-se umas às outras. Esses atributos conectam-se à tradição judaica, à medida que "o judeu que pecou permanecerá sempre judeu" (DEUTSCHER, 1970, p. 27). A ideia aqui transcende o pecado ou o não pecado, mas o preceito de que uma vez pertencente a uma tradição judaica, ultrapassa-se a divisa do judaísmo. É nessa perspectiva que Clarice e Rawet coadunam-se: os autores elevaram o pensamento acima de padrões literários e sociais, expandindo suas vidas e suas obras a novas vertentes e sentidos.

Em seus ensaios, novelas ou contos, Rawet utiliza a linguagem de forma exata, corrosiva e afiada - sobretudo quando o tema é o judaísmo, uma vez que a relação do autor com a tradição judaica foi problemática. Cercado de personagens deslocados, estranhos, caóticos, que muitas vezes vinham na figura do imigrante, do judeu errante, o autor convivia com a dualidade de pertencer à cultura judaica, mas também estar em constante desacordo com essas tradições.

Rawet sempre abordou com extrema severidade os assuntos judaicos durante sua vida. As convicções do autor sobre o judaísmo foram expressas de diversas formas durante sua trajetória, tendo como ápice dessa desgastada relação o ensaio "Kafka e a mineralidade judaica ou a tonga da mironga do kabuletê". Nesse texto, ele rompe com a comunidade judaica e critica o esvaziamento de sentido dos rituais praticados, além de avaliar com rigor o materialismo praticado por certos membros da comunidade judaica do Rio de Janeiro.

Aproveito os comentários sobre o livro de Erich Heller, Kafka, em tradução de James Amado, e publicado pela Cultrix, para fazer a minha declaração pública, a quem interessar possa, de meu desvinculamento completo e total de qualquer aspecto relacionada com a palavra judeu, familiar ou não. Não, não sou anti-semita, porque semitismo não significa necessariamente judaísmo, sou antijudeu, o que é bem diferente, porque judeu significa para mim o que há de mais baixo, mais sórdido, mais criminoso, no comportamento deste animal de duas patas que anda na vertical. (RAWET, 2008, p. 191)

De acordo com Rosana Bines, "Rawet opta por filiar-se à tradição especulativa do pensamento rabínico, perpetuada na contemporaneidade por filósofos como Martin Buber, com quem dialoga de perto em seu ensaio Eu-tu-ele" (BINES, 2008, p. 16). A questão do 
autor era a forma com que o judaísmo era praticado por alguns membros da comunidade judaica e de que maneira essas atitudes entravam em desacordo com o que era difundido, o que para Rawet soava como dissimulação. Há vários excertos de suas polêmicas declarações que mostram a visão crítica do autor sobre a comunidade judaica, como quando afirma: "Tenho a impressão de que, ao contrário do que se apregoa por aí, o povo eleito é mestre em implantar e espalhar o terror, com inteligência, evidentemente, ou sutilezas" (RAWET, 2008, p. 209). É possível pensar que o questionamento de Rawet é sobre o comportamento da comunidade, não propriamente contra a tradição judaica.

Rawet reconhece que sua formação intelectual foi positivamente influenciada por importantes figuras judaicas, posto que o próprio autor enaltece alguns filósofos judeus que fizeram parte de sua formação, como Martin Buber e Spinoza: "Creio que foi através de Buber que aprendi os primeiros elementos positivos de judaísmo. [...] Em Spinoza, velha admiração, o Tratado da reforma do entendimento me dava a dimensão do homem material, despojado de sua mitologia própria" (RAWET, 2008, p. 141). No entanto, o seu crivo ferrenho não deixava passar nem mesmo as personalidades intelectuais que tanto admirava, visto que Rawet criticava com rigidez o intelectualismo, afirmando que a pedagogia das ruas era o propulsor de sua escrita: "aprendo com o povo, sim, aprendo com o povo a reconquistar sempre meu impulso criador, nada mais, aprendo com o povo a compreender um verso de Rilke ou Rimbaud, nada mais, aprendo como o povo a perceber o que há de grande em Picasso, Miró, Chagall, e Klee” (RAWET, 2008, p. 97). Com muito empenho, Rawet buscava se dissociar da figura de intelectual e estrangeiro, na tentativa de não ser rotulado como hermético, fato comum também a Clarice Lispector. Obstinadamente, os autores desertavam de qualquer ideia que aprisionasse ou categorizasse os seus modos de escrever e fazer literatura.

Nessa perspectiva, o comportamento, as convicções e a escrita rawetiana dialogam com o entendimento de Isaac Deutscher acerca do “judeu não-judeu”. Rawet reconhecidamente manteve uma difícil relação com o judaísmo, apesar de, por vezes, admitir a influência judaica na formação de sua bagagem intelectual. Deutscher (1970, p. 28) aponta que "o judeu herege, que superou o judaísmo, pertence a uma tradição judaica”, assim o autor relembra que mesmo Marx e Spinoza, por exemplo, “ultrapassaram a divisa do judaísmo, que consideravam tão estreito, tão arcaico, tão constrangedor". Diante disso, entendemos que Rawet partilha de uma visão de que o judaísmo não abarcava seus ideais e satisfação diante da vida, sendo necessário ir além daquilo que o limitava naquele momento. Deutscher revela que "foi isso que lhes possibilitou elevar o pensamento acima de suas sociedades, suas nações, suas épocas, seus contemporâneos e expandir-se mentalmente para novos horizontes e para o 
futuro" (DEUTSCHER, 1970, p. 29).

A errância e deslocamento são marcas que percorrem toda a escrita de Rawet, seus personagens sentem-se alheios ao mundo que os cerca, sempre em busca de pertencer. É indelével a lenda do "judeu errante" presente em suas obras, por exemplo, em Viagens de Ahasverus à terra albeia em busca de um passado que não existe porque é futuro e de um futuro que já passou porque sonhado (1970), na qual o autor "nos oferece a possibilidade de vermos como um escritor judeu representa a população que criou, atualizou, estetizou e operacionalizou a lenda” (KIRSCHBAUM, 2019, p. 131). De acordo com Saul Kirschbaum (2019), nessa novela Rawet se vê representado na condição de judeu, vivendo a situação de alguém que se sente notado, por amigos, colegas, conhecidos e por si mesmo como uma encarnação do protagonista da lenda do "judeu errante", dessa forma vivificando sua sensação de estranhamento.

Os aspectos da imigração judaica no Brasil na obra rawetiana já ganham destaque na sua primeira obra Contos do imigrante. Segundo Jacó Guinsburg, o autor foi “o primeiro a dar aos assuntos a amplitude e o nível requeridos para integrá-lo nas letras nacionais" (2008, p. 76). Dessa forma, para Guinsburg, Rawet ultrapassou o arquétipo do imigrante judeu, trazendo à tona a face humana dos conflitos experienciados por seus personagens. Através de sua obra, Rawet esquadrinha a dinâmica das complexas relações humanas e suas idiossincrasias. $\mathrm{Na}$ obra inaugural de Rawet são várias as narrativas que focalizam os elementos judaicos protagonizados pelos personagens: o profeta, Ida, Judith ou o judeu assimilado que sente culpa por prosperar.

No primeiro conto encontramos o profeta, um imigrante que chega ao Brasil e é recebido pela família, entretanto não consegue estabelecer uma conexão afetiva com os parentes, uma vez que ele "vislumbrou, porém, um ligeiro engano" (RAWET, 1956, p. 11). O personagem é marcado pela cisão, pelo deslocamento, pelo estranhamento diante daqueles que imaginara que seriam fonte de afeto: "um mundo só. Supunha encontrar aquém-mar o conforto dos que como ele havia sofrido, mas que o acaso pusera, marginalmente, a salvo do pior. E conscientes disso partilhariam com ele em humildade o encontro" (RAWET, 1956, p. 11). A alcunha que o perseguia era também a determinação da diferença entre o personagem e sua família: "a palavra nunca andava sem um olhar irônico, uma ruga de riso" (RAWET, 1956, p. 12). É bem reconhecida a diáspora vivida através dos tempos pelos judeus e como o sentimento de não pertencimento acompanha aquele que deixou toda uma vida para trás. O profeta ultrapassa o sentimento de não conexão com o mundo e nos leva a focalizar a ideia de não se conectar mesmo entre os seus, aqueles que assim como ele deveriam 
compreender os horrores que vivera durante a Guerra.

Contos do imigrante é um livro de mutismos, de incompreensão e de desconexão. No conto "A prece", a personagem Ida lembra-nos que ser diferente por vezes torna-se perigoso. Nessa narrativa, o elemento judaico significativo é a prece que a personagem realiza no Shabbat. Esse período da semana é especialmente importante para os judeus, e se inicia ao anoitecer da sexta-feira e vai até o anoitecer do sábado. O Shabbat representa o dia do descanso, pois segundo a tradição, Deus descansou da criação do mundo no sétimo dia: o sábado. As formas de vivenciar o Shabbat atravessam desde rituais comuns até experiências individuais, uma vez que os judeus entendem que cada um deve encontrar sua própria forma de conexão com a data. Para Ida, o ritual era o momento de reencontro com o marido e filhos que perdera: "Isaías às sextas-feiras entrava mais alegre, o rosto brilhando, e um ou outro pingo d'água, da barba, denunciava o banho. Dava umas palmadas em suas costas (Ida tinha o rosto vermelho da lenha do forno), e ia orar. Agora, o retrato" (RAWET, 1956, p. 24). No conto rawetiano, Ida está em seu momento de vínculo profundo com suas raízes, revivendo momentos familiares através dos rituais praticados, quando sua intimidade é interrompida e devassada pela intolerância de seus vizinhos.

O sentimento do indizível e de exílio interior são frequentes na escrita rawetiana. No conto "Judith", a protagonista também tenta uma conexão com a irmã, porém não consegue instituir um elo afetivo com ela. Após a morte de seu marido, Judith busca pertencimento no seio familiar, entretanto percebe o engano: "um hiato. Talvez procurassem ambas um fio que as reatasse, mas era inexistente este" (RAWET, 1956, p. 35). A vida de Judith não difere de tantas outras mulheres que perderam suas famílias durante os horrores da Guerra, posto que era comum os maridos partirem sozinhos para outro país a fim de custear a posterior vinda dos outros membros da família. Por vezes, essas mulheres eram obrigadas a arcarem com a criação e sustento de seus filhos enquanto estavam sozinhas, aguardando melhores oportunidades. Este caso identifica-se com a própria mãe de Rawet, que passou longos meses criando os filhos sozinha até vir para o Brasil e novamente reunir toda a família.

A partir de sua posição dual diante de suas origens, Judith preserva costumes e valores judaicos, no entanto mantém uma postura de ruptura com paradigmas de comportamento. Chiarelli (2007, p. 126) explicita que "a recusa da renúncia à origem pode ser lida à luz de uma maneira pessoal da personagem se relacionar com a tradição". Ocorre o que Todorov (1999. p. 26) define como transculturação: a aquisição de um novo código sem que o antigo se perca. O modo como Judith se relaciona com o judaísmo é constituída pela coexistência 
da maneira que fora criada e arraigada aos costumes judaicos no seio familiar e a maneira como lida em sua a vida a partir do casamento.

Outra recorrência nesse período do grande fluxo imigratório é o caso do "judeu assimilado", presente no conto "Requiém para um solitário". Tal fenômeno ocorre quando o judeu se integra ao país de destino, de modo que consegue prosperar e "fazer a América", como no caso do protagonista do conto. A tão sonhada estabilidade é conquistada através de espinhosos caminhos, entretanto, resta culpa pelos semelhantes que não obtiveram êxito: "à noite, relaxando o corpo ao lado da mulher, amparava-se do medo de que a América o estava arrasando. Outros que vieram com ele e não resistiram. Foram para o interior. Que será deles?” (RAWET, 1956, p. 57). A segurança que o protagonista sentia crescia na mesma medida em que a culpa o corroía.

O receio de perder suas raízes em meio a uma nova cultura torna-se uma tormenta para o judeu assimilado. Integrar-se enquanto tantos outros não conseguiram acarreta uma pressão para o protagonista, o qual percebe a fragilidade da "ordem" instaurada. A falsa sensação de segurança é desvelada: "olhou ao redor, fixou os movéis trabalhadas. E mergulhando a cabeça no travesseiro levava consigo a imagem do que viera construindo e sentia escapar dos dedos" (RAWET, 1956, p. 61) A experiência imigratória resulta em diversos cenários e efeitos, dada a especificidade humana. Sendo assim, há múltiplas manifestações das emoções referentes a essa vivência. Talvez por isso torna-se um tanto utópica a ideia de pertencimento mesmo para o assimilado, posto que cada indivíduo possui sua maneira própria de sentir e perceber o mundo ao redor.

Rawet e Clarice possuem maneiras peculiares de escrever, pois percebiam o mundo de forma única também. Não obstante, o judaísmo foi elemento constituinte desse processo formador de suas personalidades. Entretanto, o ato de categorizar os autores em uma religião ou forma de pensar é estreitar a visão de seus escritos, algo oposto à magnitude de suas formas de ficcionalizar. Otto Lara Resende afirma que, no caso de Clarice, "seu exílio era de outra natureza" (2017, p. 293), estendemos o mesmo pensamento para Rawet, pois os autores arquitetaram na literatura um espaço de paradoxos factíveis. Nelson Vieira declara que ler Clarice é uma "experiência espiritual”, já Fausto Cunha diz que, ao ler Rawet, saímos "chamuscados". Nos dois casos podemos afirmar que a leitura da obra desses autores é sui generis, não conseguimos sair impunes a esse contato.

Retornando à pergunta inicial: quem é o judeu? Seguimos sem a resposta definitiva ao questionamento, na verdade, entendemos que a real questão seria: quais as formas de ser judeu? Como o judaísmo é vivenciado em cada indivíduo? Mais importante que procurar 
respostas, é sempre manter o questionamento, a fim de propriciar novos olhares e novas percepções, sejam elas dentro do texto literário ou não. Compreendemos que ser judeu é uma experiência particular, e como tal, possui particularidades e características diferentes para cada indivíduo. Isto posto, Rawet e Clarice expericiaram de forma própria o judaísmo em suas trajetórias. A palavra como cerne de uma escrita meticulosa, sensível e atenta; o indizível transfigurado nos textos; personagens desajustados e errantes, são algumas das características da prosa dos autores já apontadas que se conciliam com a tradição judaica. Para eles, o verdadeiro exílio é o interior, àquele em que os autores mergulham e tanto provocam em seus textos.

\section{THE JEWISH REVERSE IN RAWET'S AND CLARICE'S TALES}

ABSTRACT: There are different ways to be jewish. Due to, this research aims to approach about the marks of jewish tradition in Samuel Rawet's and Clarice Lispector's texts. Furthermore, we intend to discuss the particular way in which the authors experienced judaism. Thus, we used the notes of Amós Oz and Fania OzSalzberger, Jacob Guinsburg, Michael Brenner, as well as other studies about the subject. The jewish experience is lived singularly: either by the customs, by the jewish tradition, by sharing the same lineage or by the jewish values. Therefore, we understand that in Rawet and Clarice the judaism is experienced in their way.

KEYWORDS: Judaism; Jewish tradition; Samuel Rawet; Clarice Lispector.

\section{REFERÊNCIAS}

ADORNO, Theodor. Minima Moralia: reflexões a partir da vida lesada (Tradução Gabriel Cohn). Rio de Janeiro: Beco do Azougue, 2008.

BINES, Rosana Kohl. A palavra extrema de Rawet (Prefácio). In: RAWET, Samuel. Samuel Rawet - ensaios reunidos. Rio de Janeiro: Civilização Brasileira, 2008.

BOSI, Alfredo. História concisa da literatura brasileira. São Paulo: Cultrix, 2006. O conto brasileiro contemporâneo. São Paulo: Cultrix, 2015.

BRENNER, Michael. Breve história dos judeus. São Paulo: Martins Fontes, 2013.

CANDIDO, Antonio. Literatura e sociedade. Rio de Janeiro: Ouro sobre Azul, 2011.

CASTELLO BRANCO, Lucia; BRANDÃO, Ruth Silviano. A mulher escrita. Rio de Janeiro: Lamparina, 2004.

CHIARELLI, Stefania. Vidas em trânsito: as ficções de Samuel Rawet e Milton Hatoum. São Paulo: Annablume, 2007.

CUNHA, Fausto. Orelha da 1. ed. de Contos do imigrante. In: SANTOS, Francisco Venceslau dos (Org.). In: Samuel Rawet: fortuna crítica em jornais e revistas. Rio de Janeiro: Editora Caetés, 2008.

COUTINHO, Edilberto. Uma mulher chamada Clarice Lispector. In: . Criaturas de papel: temas de literatura e sexo \& folclore \& carnaval \& futebol \& televisão \& outros temas da vida. Rio de Janeiro/ Brasília, Civilização Brasileira/ INL, 1980.

DERRIDA, Jacques. A escritura e a diferença. São Paulo: Perspectiva, 1995. 
DEUTSCHER, Isaac. O judeu não-judeu e outros ensaios. Rio de Janeiro: Civilização Brasileira, 1970.

GUINSBURG, Jacó. Aventuras de uma lingua errante. São Paulo: Perspectiva, 1996.

. Os imigrantes de Samuel Rawet. In: SANTOS, Francisco Venceslau dos (Org.). Samuel Rawet. fortuna crítica em jornais e revistas. Rio de Janeiro: Editora Caetés, 2008.

GOTLIB, Nádia. Clarice: uma vida que se conta. São Paulo: Editora Ática, 1995.

IGEL, Regina. Imigrantes judeus/ Escritores brasileiros: o componente judaico na literatura brasileira. São Paulo: Perspectiva, 1997.

JOZEF, Bella. Clarice Lispector, a quarta dimensão da palavra. In: LEWIN, Helena (coord.). Judaísmo e modernidade: suas múltiplas inter-relações. Rio de Janeiro: Centro Edelstein de Pesquisas sociais, 2009.

KIRSCHBAUM, Saul. Representar, ser representado, ver-se representado: a imagem do estranho na obra de Samuel Rawet. In: CHIARELLI, Stefania; BINES, Rosana Kohl; MATA, Anderson da (Orgs.). Rawet em diálogo. Campinas: Pontes Editores, 2019.

LIMONCIC, Flavio. Um mundo em movimento: a imigração asquenaze nas primeiras décadas do século XX. In: GRINBERG, Keila. (Org.). Os judeus no Brasil. Inquisição, imigração e identidade. Rio de Janeiro: Civilização Brasileira, 2005, p. 253-286.

LISPECTOR, Clarice. Laģos de família. Rio de Janeiro: Francisco Alves, 1960.

- A descoberta do mundo. Rio de Janeiro: Rocco, 1999.

Berna, 14 de agosto de 1946. In: SABINO, Fernando. Cartas perto do coração. Rio de

Janeiro: Record, 2011.

- A hora da estrela. Rio de Janeiro: Rocco, 2017.

OZ, Amós; OZ-SALZBERGER, Fania. Os judeus e as palavras. São Paulo: Companhia das Letras, 2015.

RAWET, Samuel. Contos do imigrante. Rio de Janeiro: José Olympio, 1956.

. Samuel Rawet - ensaios reunidos. Rio de Janeiro: Civilização Brasileira, 2008.

RESENDE, Otto Lara. O principe e o sabiá. São Paulo: Companhia das Letras, 2017.

VIEIRA, Nelson. A linguagem espiritual de Clarice Lispector. In: Travessia. Revista do curso de Pós-Graduação em Literatura brasileira. Florianópolis: UFSC, no 14, 1987.

A expressão judaica na obra de Clarice Lispector. In: Remate de Males n. 9 (Orgs.

Vilma Arêas e Berta Waldman). Campinas: IEL/Unicamp, 1989.

Ser judeu e escritor - três casos brasileiros.... In: SANTOS, Francisco Venceslau dos (Org.). Samuel Rawet: fortuna crítica em jornais e revistas. Rio de Janeiro: Editora Caetés, 2008.

WALDMAN, Berta. Entre passos e rastros: presença judaica na literatura brasileira contemporânea. São Paulo: Perspectivas, 2003.

Recebido em: 09/07/2020.

Aprovado em: 12/11/2020. 